Des. Dev., 21, 706 (1982).

13) Ueyama, K., S. Morooka, K. Koide, H. Kaji and T Miyauchi: Ind. Eng. Chem., Process Des. Dev., 19, 592 (1980).

14) Wallis, G. B.: "One-dimensional Two-phase Flow," McGraw-Hill, New York (1969).
15) Yasunishi, A., M. Fukuma and K. Muroyama: Kagaku Kogaku Ronbunshu, 12, 420 (1986).

16) Yasunishi, A., M. Fukuma and K. Muroyama: J. Chem. Eng. Japan, 19, 444 (1986).

\title{
PARAMETER ESTIMATION IN A COOLING TOWER PROCESS
}

\author{
ISAMI YOSHIFUKU
}

Department of Chemical Engineering, Kagoshima University, Kagoshima 890

\begin{abstract}
Key Words: Parameter Estimation, Cooling Tower Process, Flowgraph Representation, Process Simulation, Computational Technique
\end{abstract}

In the previous paper, ${ }^{1)}$ the solution to the packed tower process problem was proposed in the form of sequential cell flowgraph representation. There, the design problem of determining the tower height subject to the known input-output conditions data and the known parameter values (volumetric coefficients of heat and mass transfer) was treated. Alternatively, the parameter estimation subject to the known tower height and the known input-output conditions data is important for cases where a process is in operation.

In this report, a computational technique for parameter estimation in a packed tower process is proposed with the aim of eliminating the troublesome graphical routine, and an application to a cooling tower process is shown.

\section{Proposed Method}

The following algorithm for the parameter estimation in a packed tower process is proposed, where sequential cell flowgraph representation is used:

1) The height of tower $Z$ is divided into $N$ equal parts, and fundamental equations for the $n$-th part (called the $n$-th cell) from the tower bottom are arranged, using a model with gas phase, liquid phase, and interface.

2) Individual fundamental equation is converted to flowgraph unit and all units are combined to form an $n$-th cell flowgraph. A sequential cell flowgraph is constructed by arranging the $n$-th cell flowgraph simplified in boxed cell from $n=1$ to $N$.

3) Using the multi-variable searching technique in the sequential cell flowgraph, the value of the parameter is estimated as a limit when $\Delta z$ goes to zero.

Received September 27, 1986. Correspondence concerning this article should be addressed to I. Yoshifuku.

\section{Application to a Cooling Tower Process Problem}

A problem is proposed for estimating the values of the volumetric coefficients of heat and mass transfer in a cooling tower process, subject to the following data: temperature of air and water at tower top and bottom $t_{\mathrm{GT}}, t_{\mathrm{GB}}, t_{\mathrm{LT}}, t_{\mathrm{LB}}$, humidity of air at tower top and bottom $H_{\mathrm{T}}, H_{\mathrm{B}}$, dry air flow rate $G$, flow rate of water at tower top $L_{\mathrm{T}}$, specific heat of water $C_{\mathrm{PL}}$, and tower height $Z$.

As for steps 1 and 2, the model, the fundamental equations of the $n$-th cell and the $n$-th cell flowgraph are shown in the literature. ${ }^{1)}$ Since the volumetric coefficient of heat transfer $h_{\mathrm{Gn}} a$ in the Lewis equation depends on the cell number, its value should be determined as the average value between the tower top and bottom. A sequential cell flowgraph is sown in Fig. 1, where the following equations are used:

$$
\begin{gathered}
N=Z / \Delta Z \\
d v 2=d v H+d v L+d v t_{\mathrm{L}}+d v t_{\mathrm{G}}
\end{gathered}
$$

Calculation will be commenced in the first cell with left-hand side variables $t_{\mathrm{GB}}, H_{\mathrm{B}}, L_{\mathrm{B}}, t_{\mathrm{LB}}, Z$ and $\Delta Z$, together with $\mathrm{h}_{\mathrm{L}} a$ and $k_{\mathrm{H}} a$. Cell-by-cell calculation must be continued to the $N$-th cell, where $N$ is an integer determined by Eq. (1).

Since there is one-to-one correspondence between two parameters and $d v 2$ in Eq. (2), we can determine $h_{\mathrm{L}} a$ and $k_{\mathrm{H}} a$ so as to minimize $d v 2$ for a small value of $\Delta Z$, using the multi-variable searching technique. This problem is denoted as follows:

$$
h_{\mathrm{L}} a, k_{\mathrm{H}} a: d v 2=\min .
$$




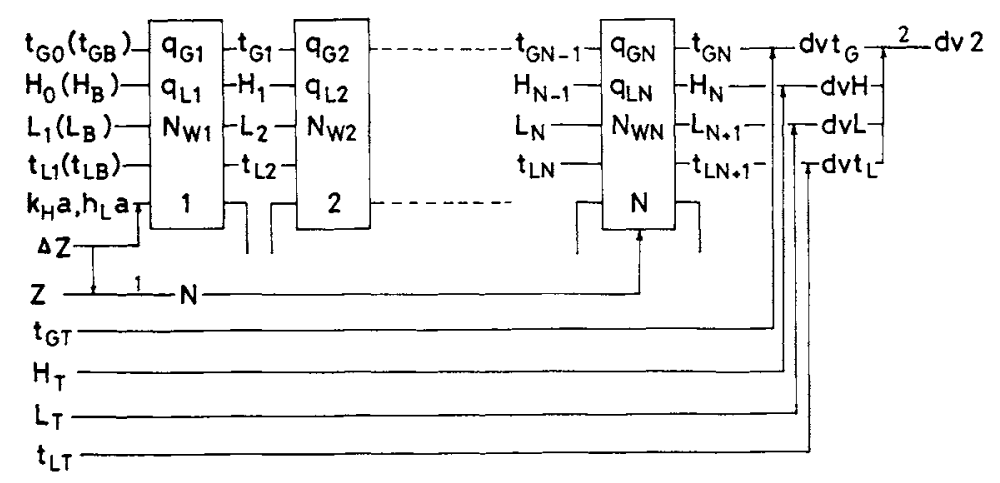

Fig. 1. Sequential cell fiowgraph.

A numerical example problem ${ }^{1)}$ of determining the parameter values $h_{\mathrm{G}} a, h_{\mathrm{L}} a$ and $k_{\mathrm{H}} a$ subject to the following data will be treated: $Z=0.724, t_{\mathrm{LB}}=20.1$, $t_{\mathrm{LT}}=36, t_{\mathrm{GB}}=35, t_{\mathrm{GT}}=27.6, H_{\mathrm{B}}=0.006, H_{\mathrm{T}}=0.0223$, $L_{\mathrm{T}}=0.5, G=1.0278, C_{\mathrm{PL}}=4.184$. The value of $L_{\mathrm{B}}$ is calculated from $L_{\mathrm{B}}=L_{\mathrm{T}}-G\left(H_{\mathrm{T}}-H_{\mathrm{B}}\right)$ as 0.4832 .

The two-variable searching problem was solved by the Simplex method with starting values of $h_{\mathrm{L}} a=50$ and $k_{\mathrm{H}} a=10$. As a result, the plots of $h_{\mathrm{L}} a$ and $k_{\mathrm{H}} a$ vs. $\Delta Z$ are shown in Figs. 2 and 3, respectively.

As step 3, we adopt $h_{\mathrm{L}} a=59.0$ by curve approximation and $k_{\mathrm{H}} a=3.69$ by line approximation, and these values are comparable with $h_{\mathrm{L}} a=60.42$ and $k_{\mathrm{H}} a=3.611$, which are used in the design problem. This discrepancy is probably attributed to the convergence technique in the method used.

Finally, the Lewis equation gives the value of $h_{\mathrm{G}} a$ :

$$
h_{\mathrm{G}} a=C_{\mathrm{Hav}} \cdot k_{\mathrm{H}} a=(1.0306) \cdot(3.69)=3.80
$$

where $C_{\mathrm{Hav}}$ is the averaged value of $C_{\mathrm{H}}$ between tower top and bottom.

\section{Acknowledgment}

The authors is grateful to Professor M. Matsubara of Nagoya Univ. for his guidance.

\section{Nomenclature}

$\begin{array}{ll}C_{\mathrm{H}} & =\text { humid heat of air } \\ C_{\mathrm{PL}} & =\text { specific heat of liquid } \\ d v & =\text { deviation } \\ G & =\text { dry air flow rate } \\ H & =\text { humidity of air } \\ h_{\mathrm{G}} a & =\text { volumetric heat transfer coefficient in } \\ & \text { gas phase } \\ h_{\mathrm{L}} a & =\text { volumetric heat transfer coefficient in } \\ & \text { liquid phase } \\ k_{\mathrm{H}} a & =\text { volumetric mass transfer coefficient } \\ L & =\text { liquid flow rate } \\ N & =\text { number of divisions } \\ Z & =\text { height of tower } \\ \Delta Z & =\text { height of cell }\end{array}$

$[\mathrm{kJ} / \mathrm{kg} \cdot \mathrm{K}]$
$[\mathrm{kJ} / \mathrm{kg} \cdot \mathbf{K}]$
$[--]$
$\left[\mathrm{kg} / \mathrm{m}^{2} \cdot \mathrm{s}\right]$
$[\mathrm{kg} / \mathrm{kg}]$
$\left[\mathrm{kW} / \mathrm{m}^{3} \cdot \mathrm{K}\right]$
$\left[\mathrm{kW} / \mathrm{m}^{3} \cdot \mathrm{K}\right]$
$\left[\mathrm{kg} / \mathrm{m}^{3} \cdot \mathrm{s}\right]$
$\left[\mathrm{kg} / \mathrm{m}^{2} \cdot \mathrm{s}\right]$
$[-]$
$[\mathrm{m}]$
$[\mathrm{m}]$

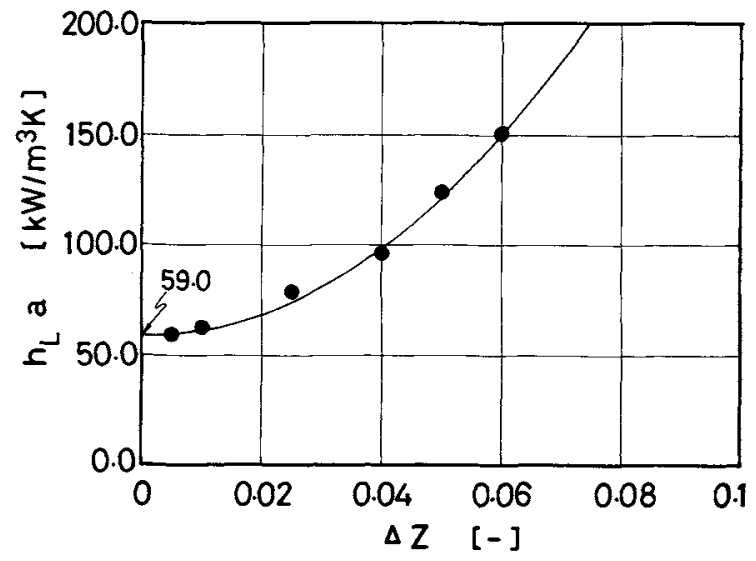

Fig. 2. Relationship between $h_{1} a$ and $\Delta Z$

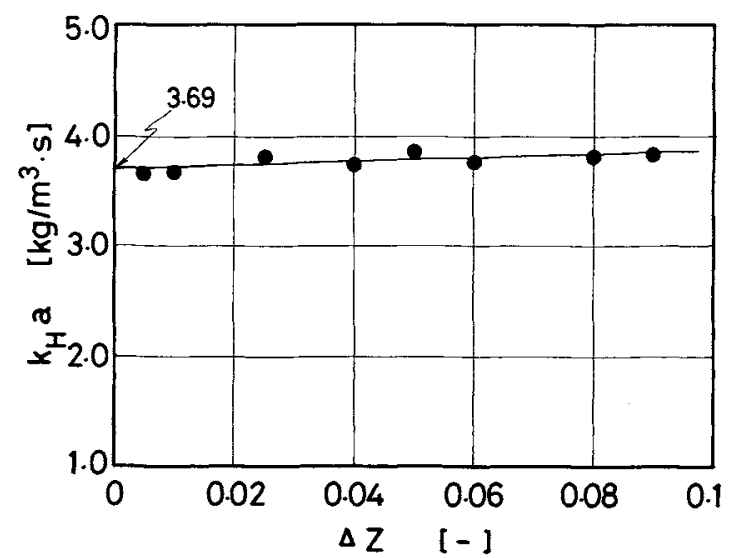

Fig. 3. Relationship between $k_{\mathrm{H}} a$ and $\Delta Z$.

$\langle$ Subscripts〉

$$
\begin{array}{ll}
B & =\text { tower bottom } \\
n & =\text { number of cell from tower bottom } \\
T & =\text { tower top }
\end{array}
$$

\section{Literature Cited}

1) Yoshifuku, I.: J. Chem. Eng. Japan, 18, 137 (1985). 